\title{
Pontocerebelární hypoplazie
}

\author{
MUDr. Tereza Svrčinová, MUDr. Vladimíra Sládková, Ph.D., MUDr. Michaela Kaiserová, Ph.D., \\ prof. MUDr. Petr Kaňovský, CSc.
}

Neurologická klinika FN a LF UP Olomouc

\begin{abstract}
Pontocerebelární hypoplazie je skupina vzácných dědičných onemocnění, do současnosti bylo popsáno osm podtypů, přičemž pontocerebelární hypoplazie typ 1 a typ 2 jsou nejčastější. Klinicky se manifestují prenatálně nebo časně postnatálně psychomotorickou retardací, hypotonií či naopak spasticitou, u většiny pacientů je př́tomna mikrocefalie a rozvijí se epileptické záchvaty. Diagnostika je založena na genetickém vyšetření, kdy je známo několik kauzálních genů, a na vyšetření magnetickou rezonancí s typickým nálezem výrazné hypoplazie mozečku a různě intenzivně vyjádřené hypoplazie pontu. Prezentujeme kazuistiku dvou sester se zpomaleným psychomotorickým vývojem, kvadruspasticitou, těžkou mentální retardací a epileptickými paroxyzmy. Zobrazení MR u obou potvrdilo těžkou hypoplazii mozečku s menším postižením pontu.
\end{abstract}

Klíčová slova: pontocerebelární hypoplazie, diferenciální diagnostika cerebellárních ataxií, genetika.

\section{Pontocerebellar hypoplasia}

Pontocerebellar hypoplasia is a group of heterogeneous inherited disorders. There have been reported eight different subtypes up to now, but the most common are type 1 and 2 . Usually have prenatal or early postnatal onset, typically it is manifested by severe psychomotor retardation with hypotonia or on the other hand with spasticity. Most of the patient has microcephaly and during the disease there are reported seizures. The diagnosis is based on genetic testing, nowadays are known several causal genes and on neuroimaging with characteristic hypoplasia and atrophy of the cerebellum and variable pontine atrophy. We documented the case report of two sisters with delay psychomotor development, they have severe mental retardation and severe motor impairment with kvadruspasticity. There have been reported epileptic seizures and MR confirm hypoplasia of the cerebellum and pons.

Key words: pontocerebellar hypoplasia, differential diagnosis of cerebellar ataxias, genetics.

\section{Úvod}

Pontocerebelární hypoplazie (PCH) jsou heterogenní skupinou vzácných onemocnění převážně s autosomálně recesivním typem dědičnosti. Manifestují se již prenatálně nebo časně postnatálně svalovou hypotonií, dyskinezami nebo naopak dystonií a spasticitou, vše provázeno zpomalením psychomotorického vývoje. Podkladem této symptomatiky je atrofie zejména infratentoriálních struktur, a to cerebella, pontu a olivárního jádra, postupně postihuje i bazální ganglia a kortex (Barth et al., 1993). Primární príičinou tohoto postižení je zřejmě chybná migrace neuronů ze společné germinální zóny v 5. gestačním týdnu (Rudnik et al., 2014).
Podle specifických klinických, radiologických a genetických znaků bylo dosud popsáno osm podtypů PCH (Maraş Genc et al., 2015). V minulosti se rozeznávaly pouze 2 typy pontocerebelárních hypoplazií - typ 1 ( $\mathrm{PCH} 1)$ a typ 2 (PCH2), které i nyní patří k nejčastějším. Ostatní varianty jsou raritní. Typicky se tato onemocnění manifestují již v prvních měsících života retardací psychomotorického vývoje (Rudnik et al., 2014). Postižení kortikálních a subkortikálních jader vede $k$ dystonickým projevům a spasticitě, přidávají se epileptické záchvaty a porucha zraku, včetně okohybných poruch. U pacientů s fenotypem PCH1 dominuje neuromuskulární slabost, hypotrofie až atrofie svalů v důsledku léze spinálních motoneuronů. Dosti často je tato jednotka zaměňována za spinální svalovou atrofii Werdning-Hoffmann. PCH2 charakterizuje spasticita a dyskineze (Namavar et al., 2011).

Pontocerebelární hypoplazie typ 1 se manifestuje již prenatálně nebo v raném novorozeneckém věku potížemi s prríjmem potravy a dechovými obtižemi. Generalizovaná svalová hypotonie a progredující svalové atrofie vedou později ke zpomalení motorického vývoje, řeči a okohybným poruchám. Mikrocefalie postihuje asi polovinu pacientů a na rozdíl od ostatních typů PCH není tak markantní (Rudnik et al., 2014). Pontocerebelárníhypoplazie typ 2 se vyskytuje nejfrekventněji, v současnosti rozeznáváme další 
Tab. 1. Typy pontocerebellárních hypoplazií

\begin{tabular}{|c|c|c|c|c|c|c|c|c|}
\hline Tyр PCH & Gen & Počátek příznaků & Přežití & Intelekt & Mikrocefalie & Epilepsie & Oční vyšetření & Dyskineze \\
\hline $1 \mathrm{~A}$ & VRK1 & prenatálně & dopělost & IQ 50-70 & ano & ne & normální & ne \\
\hline \multirow[t]{3}{*}{ 1B } & $\begin{array}{l}\text { EXOS3 } \\
\text { homozygot D132A }\end{array}$ & kojenecký věk & dospělost & IQ 20-50 & možná & možná & $\begin{array}{l}\text { nystagmus, } \\
\text { strabizmus }\end{array}$ & ne \\
\hline & $\begin{array}{l}\text { EXOS3, mutace } \\
\text { D132A+jiné }\end{array}$ & novorozenecký věk & dětství & IQ 20-30 & možná & možná & nystagmus & ne \\
\hline & EXOS3+jiné mutace & prenatálně & dny & NA & ne & ne & normální & ne \\
\hline $2 \mathrm{~A}$ & TSEN54 & prenatálně/novorozenecký věk & různé & IQ 50-70 & ano & ano & normální & ano \\
\hline $2 \mathrm{~B}$ & TSEN2 & prenatálně/novorozenecký věk & dospělost & IQ pod 20 & ano & ano & normální & ano \\
\hline $2 \mathrm{C}$ & TSEN34 & novorozenecký věk & různé & IQ pod 20 & ano & ano & normální & ano \\
\hline $2 \mathrm{D}$ & SEPSECS & novorozenecký věk & dětství & IQ pod 20 & ano & ano & nystagmus & ano \\
\hline 3 & $\begin{array}{l}\text { neznámý, lokus je } \\
\text { na chromozomu 7q }\end{array}$ & novorozenecký věk & různé & IQ pod 20 & ano & ano & optická atrofie & ne \\
\hline 4 & TSEN54 & prenatálně & hodiny/dny & NA & ano & ano & NA & ano \\
\hline 5 & TSEN54 & prenatálně & hodiny/dny & NA & ano & ano & NA & ano \\
\hline 6 & RARS2 & novorozenecký věk & týdny/měsíce & NA & ano & ano & normální & ne \\
\hline 7 & neznámý & novorozenecký věk & měsíce & NA & ano & ano & NA & ne \\
\hline 8 & CHMP1A & batolecí věk & mládí & IQ 20-35 & ano & ano & $\begin{array}{l}\text { strabizmus, } \\
\text { ptóza }\end{array}$ & ano \\
\hline
\end{tabular}

N/A - nedostupné

4 subtypy. Od PCH1 se liší predevším absencí svalových atrofií. Iniciálními př́iznaky jsou poruchy polykání a sání, prìdružují se generalizované dystonické a choreatické dyskineze a epileptické záchvaty (Maraş Genc et al., 2015). Typická je mikrocefalie, která dosahuje až -6,5 směrodatné odchylky oproti normálním hodnotám. Délka přežití je různá, pohybuje se v rozmezí několika málo měsíců až po dospělý věk. Stejně tak jsou rozdílné i motorické dovednosti nemocných, od pacientů neschopných sedu po pacienty schopné samostatné chůze (Namavar et al., 2011). Nemocných s pontocerebelární hypoplazií typu 3 bylo popsáno pouze několik sporadických prípadů, u kterých nebyla zjištěna specifická genová mutace, nicméně defekt byl lokalizován na dlouhém raménku 7. chromozomu. Ke klinickým projevưm patří generalizovaná svalová hypotonie, epileptické záchvaty a mikrocefalie, specifická je atrofie optického nervu a kraniofaciální dysmorfizmus (Rudnik et al., 2014). Pontocerebelární hypoplazie typu 4 je velmi vzácná a vede k časným novorozeneckým úmrtím. Manifestuje se již krátce po narození myoklony, hypertonem a kontrakturami s progredující respirační insuficiencí, která vyžaduje časně umělou plicní ventilaci (Rudnik et al., 2014).

Pontocerebelárníhypoplazie typ 5 se projevuje již prenatálně myoklony u plodu, kdy se dítě rodí mrtvé nebo zmírá krátce po porodu (Patel et al., 2006). Pontocerebelární hypoplazie typ 6 charakterizuje mutace genu RARS2 kódujícího mitochondriální translaci. Již postnatálně děti trpí generalizovanou hypotonií, epileptickými záchvaty a mikrocefalií, bývá prítomna laktátová acidóza. Postižení přežívají pouze měsíce (Joseph et al., 2014). Pontocerebelární hypoplazie typ 7 představuje kombinaci PCH projevující se svalovou hypotonií, epileptickými paroxyzmy a respirační insuficiencí s apnoickými pauzami a primárního hypogonadizmu. Kauzální gen nebyl nalezen. Doba přežití je asi půl roku (Anderson et al., 2011). Pontocerebelární hypoplazie typ 8 se projevuje retardací psychomotorického vývoje, svalovou hypotonií a parézami okohybných nervů (často ptóza víčka, strabizmus). Onemocnění je podmíněno defektem CHMP1A genu (Mochida et al., 2012).

\section{Kazuistika}

Zdokumentovali jsme prípad 27leté ženy narozené z fyziologické gravidity, v termínu, s normální poporodní adaptací. Třetí den po porodu se u ní objevily myoklony $v$ obličeji bez průvodní kvalitativní či kvantitativní poruchy vědomí, které byly zcela refrakterní k podávané terapii a vyskytovaly se až do jednoho roku života. Současně byl zaznamenán zpomalený psychomotorický vývoj se schopností chůze od 18 měsíců a s rozvojem řeči až ve 3 letech života, v dokumentaci byla popisována mentální retardace (IQ 50). V objektivním neurologickém nálezu zpočátku dominovala ataxie chưze, třes končetin, řeč byla výrazně dysartrická a monotónní. Mikrocefalie nebyla popisována. V dalším vývoji onemocnění, asi v 6 letech, došlo k rozvoji spastické kvadruparézy s dominantním postižením dolních končetin. Bylo provedeno EEG, kde byl popsán špatně organizovaný graf s generalizovanou pomalou aktivitou svědčíci pro difuzní encefalopatii. Na MR mozku byla popsána těžká atrofie mozečku a diskrétní atrofie pontu. Byla vyloučena dědičná metabolická, střádavá, mitochondriální a peroxisomální onemocnění, včetně poruch glykosylace. Genetickým vyšetřením byla vyloučena Friedreichova ataxie.

$\checkmark 18$ letech věku se přidala fokální dystonie na horních končetin a cervikální dystonie charakteru torticollis. Od 20 let pacientka trpí generalizovanými epileptickými paroxyzmy s tonicko-klonickými křečemi končetin. V únoru tohoto roku ve 27 letech věku došlo k nakupení epileptických záchvatů a ke zhoršení celkového stavu. V klinickém obraze dominuje výrazná cerebelární ataxie se statickým a intenčním tremorem, při prijietí na kliniku nebyla pacientka schopna chůze pro výraznou nestabilitu a spasticitu dolních končetin. Na kontrolním EEG je patrný abnormní graf se smíšenou specifickou ostrou aktivitou na hrubě porušeném pozadí. Kontrolní MR vyšetření mozku potvrzuje výraznou atrofii zejména mozečkových hemisfér a v menší míře i mozkového kmene. Po zahájení terapie levetiracetamem již nedošlo k recidivě epileptických paroxyzmů. $\vee$ průběhu hospitalizace byla zahájena rehabilitace se zaměřením na zlepšení posturální stability, takže $v$ době dimise byla pacientka opět schopna chůze s oporou dvou francouzských holí.

Psychomotorická retardace je prítomna i u o 4 roky starší sestry nemocné, u které se již v časném dětství rozvinula generalizovaná 
Obr. 1. EEG graf: abnormní záznam pro generalizovanou zpomalenou aktivitu

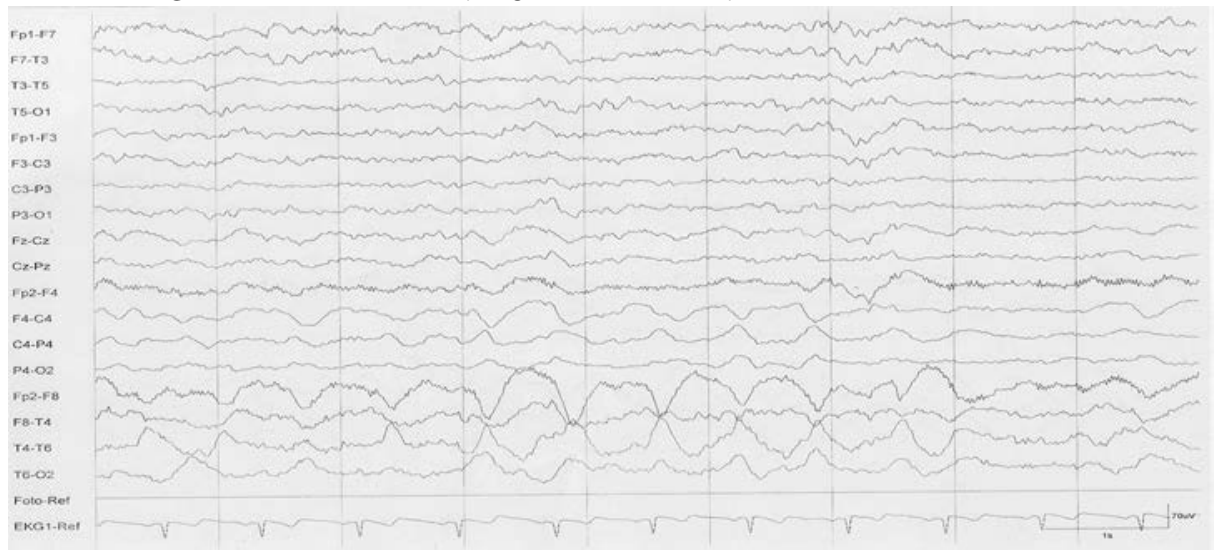

Obr. 2. MR mozku: Na FLAIR sekvencích je u staršísestry patrno normální rozložení šedé a bilé hmoty, bez ložiskových či difuznich změn signálu mozkovétkánè. Hypoplazie mozečku s rozširénými subarachnoidálními prostory

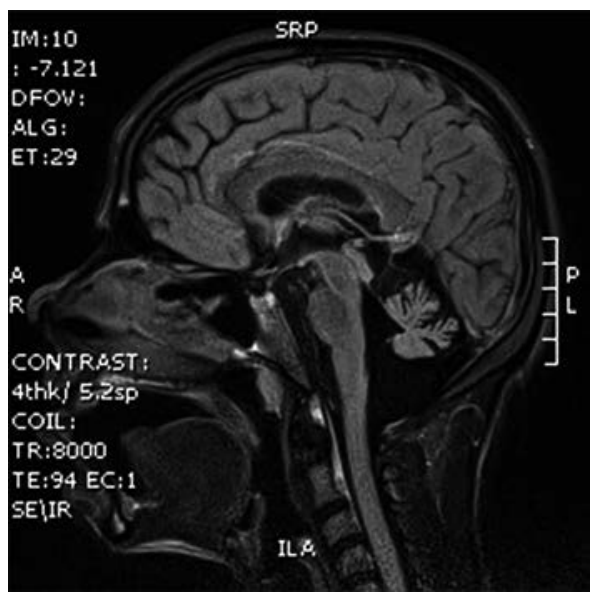

Obr. 3. MR mozku: U mladší sestry je na T1 vážených obrazech pospána hypoplazie mozečku s prohloubenou gyrifikací a rozšǐrením IV. komory. Gracilnější naprímený mozkový kmen

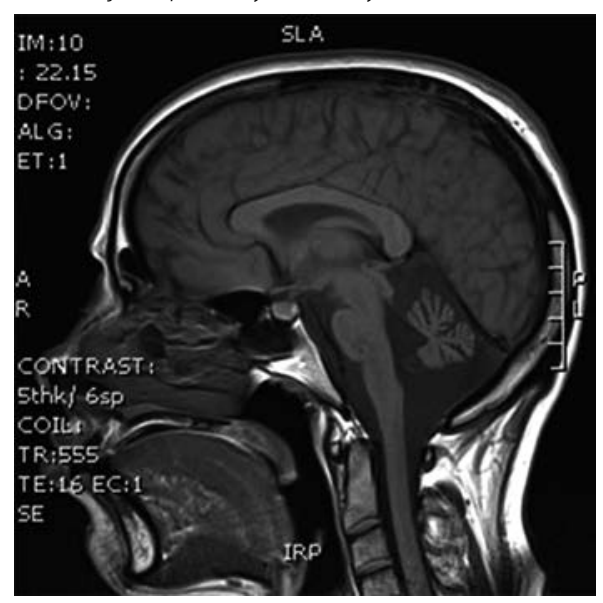

svalová hypotonie. Ve 3 týdnech věku se prìdaly generalizované tonicko-klonické křeče končetin s poruchou vědomí, které byly stejně jako u sestry zcela refrakterní k terapii. Tyto křečové stavy spontánně zcela vymizely v 8 měsících věku. Následně byla pacientka umístěna do ústavu sociální péče. Nyní je v neurologickém nálezu prítomna kvadruspasticita s kontrakturami svalstva končetin, dysmorfické rysy obličeje, skolióza páteře a těžká mentální retardace. Úroveň jejích psychomotorických dovedností nepřekročil 3. trimenon. Není schopna samostatného sedu ani užitečné řečové produkce, neb vydává pouze neartikulované zvuky, je zcela inkontinentní. Při zobrazení mozku pomocí MR v nálezu dominuje výrazná hypoplazie mozečku a lehká atrofie pontu.

Vzhledem ke klinické manifestaci, pozitivní rodinné anamnéze a nálezu na MRI jsme pojali suspekci na onemocnění z okruhu pontocerebelárních hypoplazií. U pacientky a prímých príbuzných byla odebrána DNA ke genetickému vyšetření, jehož výsledek není dosud k dispozici.

\section{Diskuze}

Diferenciální diagnostika PCH je široká. Z nejčastějších jednotek je nutno vyloučit především kongenitální poruchy glykosylace, spinální muskulární atrofii a mozečkové degenerace.

Kongenitální poruchy glykosylace jsou skupinou onemocnění způsobených defektem enzymů účastnících se syntézy oligosacharidových řetězců glykoproteidů. Nejčastější typ 1A (CDG1A - congenital disorders of glycosylation typ 1A) je způsoben mutací genu PMM2. Projevuje se retardací psychomotorického vývoje, generalizovaným svalovým hypotonem, epileptickými záchvaty, strabizmem a hypogonadizmem s abnormním rozložení tukové tkáně. Na zobrazení MR je popisována atrofie mozečku (Magner et al., 2012). Především PCH1 by měly být odlišeny od spinální muskulární atrofie typ I známé jako Werdning-Hoffmannova nemoc. Jedná se o autosomálně recesivně dědičné onemocnění, kde defekt SMN1 genu vede k degeneraci míšních motoneuronů. Projevuje se již brzy po narození generalizovanou svalovou slabostí a zpomalením pouze motorického vývoje, kdy postižené děti umírají do 18 měsíců v důsledku respiračního selhání. Při vyšetření MRI nenacházíme atrofii mozečku ani pontu (Prior et al., 2014).

Ze skupiny mozečkových degenerací je nutno vyloučit především jednotky manifestují se kongenitálně nebo v raném dětství. Kongenitální ataxie je typická pro Marinesco-Sjögrenův syndrom, vzácné autosomálně recesivně dědičné onemocnění provázené mozečkovou atrofií způsobené mutací SIL1 genu. Manifestuje se cerebelární ataxií, kataraktou, svalovým hypotonem, mentální retardací, hypogonadizmem, deformitami skeletu a okohybnými poruchami. Přesto není délka života významněji ovlivněna (Anttonen et al., 2006).

Friedreichova ataxie je nejběžnější hereditární ataxií s autosomálně recesivním typem dědičnosti. Je způsobena genetickým defektem na dlouhém raménku chromozomu 9, který vede k intronové expanzi tripletu GAA. Klinicky se manifestuje do 20 let věku postupně progredující ataxií, včetně ataxie chůze, dysartrií, svalovou slabostí, spasticitou na dolních končetinách provázenou šlachově-okosticovou areflexií a poruchou propriocepce. Je asociována s kardiomegalii, diabetem mellitem a deformitou nohy zvanou pes equinovarus, neboli Friedreichova noha. Kognitivní funkce jsou intaktní (Sanjay et al, 2014). Zobrazení MR je v prvních fázích onemocnění často normální, zde Ize využít napríklad susceptibilně vážené sekvence (susceptibility weighted imaging SWI), na kterých byla pospána atrofie cerebelárních jader (Bareš et al., 2015). Postupně však Ize prokázat na MR atrofii mozečku, především horního mozečkového pedunkulu, a krční míchy (Sanjay et al., 2014).

Ramsay-Huntův syndrom neboli progresivní myoklonická ataxie je vzácné onemocnění s autosomálně recesivním typem dědičnosti způsobené mutací GOSR2 genu. První projevy přicházejí do 20 let věku. Patří k nim ataxie, myoklonus provokovaný senzitivním stimulem a epileptické záchvaty. MR mozku bývá bez patologie, někdy je popisována diskrétní atrofie vermis (Boissé et al., 2013).

Další ataxií manifestující se $v$ dětském věku je nemoc Luis-Barové, neboli ataxia teleangiektasia, která se projevuje progredující ataxií, 
SDĚLENÍ Z PRAXE 【

PONTOCEREBELÁRNÍ HYPOPLAZIE

mentální retardací, teleangiektáziemi zejména na spojivce, choreoatetózou a okulomotorickou apraxií. Onemocnění je často provázeno imunodeficitem a zvýšeným rizikem rozvoje malignit, hlavně lymfoproliferace. Jedná se o autosomálně recesivně dědičné onemocnění způsobené mutací ATM genu. Atrofie mozečku se vyvijí až v pokročilém stadiu onemocnění (Gatti et al., 1999).

Z dalších onemocnění je nutno vyloučit i některé formy spinocerebelárních ataxií. Jedná se o heterogenní skupinu autosomál-

\section{LITERATURA}

1. Anderson C, Davies JH, Lamont L, Foulds N. Early pontocerebellar hypoplasia with vanishing testes: A new syndrome? Am J Med Genet A. 2011; 155A: 667-672.

2. Anttonen AK, Lehesjoki AE. Marineco-Sjogren syndrome GeneReviews ${ }^{\otimes}$ [Internet]. Seattle (WA): University of Washington, Seattle; 1993-2016. 2006 Nov 29.

3. Bareš M, Apps R, Kikinis Z, Timmann D, Oz G, Ashe JJ, Loft M, Koutsikou S, Cerminara N, Bushara KO, Kašpárek T. Proceedings of the workshop on Cerebellum, Basal Ganglia and Cortical Connections Unmasked in Health and Disorder held in Brno, Czech Republic, October 17th, 2013. Cerebellum. 2015 Apr; 14(2): 142-150. doi: 10.1007/s12311-014-0595-y.

4. Barth PG. Pontocerebellar hypoplasias. An overview of a group of inherited neurodegenerative disorders with fetal onset. Brain Dev. 1993; 15: 411-422.

5. Bidichandani SI, Delatycki MB. Friedreich Ataxia Synonym: FRDA, Initial Posting: December 18, 1998; Last Update: July 24, 2014

6. Boissé Lomax L, Bayly MA, Hjalgrim H, Møller RS, Vlaar AM, Aaberg KM, Marquardt I, Gandolfo LC, Willemsen M, Kamsteeg EJ, O'Sullivan JD, Korenke GC, Bloem BR, de Coo IF, Verhagen JMA, Said I, Prescott T, Stray-Pedersen A, Rasmussen M, Vears DF, Lehesjoki AE, Corbett MA, Bahlo M, Gecz J, ně dominantně dědičných onemocnění, které jsou způsobeny degenerací neuronů cerebella a jeho drah. Do současnosti bylo identifikováno více než 30 genů, jejichž mutace vede k rozvoji SCA. V dětství nebo adolescenci se manifestují jen některé z nich, a to SCA 5, 7, 10, 11, 13, 14, 17 a 28. Klinicky se manifestují ataktickou chůzí, nekoordinovanými pohyby končetin, dysartrií, u některých typů mohou být prítomny okohybné poruchy, známky postižení periferního nervového systému nebo extrapyramidová symptomatika (Bushart et al., 2016).

Dibbens LM, Berkovic SF. 'North Sea' progressive myoclonus epilepsy: phenotype of subjects with GOSR2 mutation. Brain. 2013 Apr; 136(Pt 4): 1146-1154. doi: 10.1093/brain/awt021. Epub 2013 Feb 28

7. Bushart DD, Murphy GG, Shakkottai VG. Precision medicine in spinocerebellar ataxias: treatment based on common mechanisms of disease. Ann Transl Med. 2016 Jan; 4(2): 25. doi: 10.3978/j.issn.2305-5839.2016.01.06. Review.

8. Feraco P, Mirabelli-Badenier M, Severino M, Alpigiani MG, Di Rocco M, Biancheri R, Rossi A. The shrunken, bright cerebellum: a characteristic MRI finding in congenital disorders of glycosylation type 1a. AJNR Am J Neuroradiol. 2012; 33: 2062-2067.

9. Joseph JT, Innes AM, Smith AC, Vanstone MR, Schwartzentruber JA, Bulman DE, Majewski J, Daza RA, Hevner RF, Michaud J, Boycott KM; FORGE Canada Consortium. Neuropathologic features of pontocerebellar hypoplasia type 6. J Neuropathol Exp Neurol. 2014; 73(11): 1009-1025.

10. Magner M, Veselá K, Hansíková H, Zeman J, Honzík T. Kazuistika dívky s dědičnou poruchou glykosylace. Pediatr. praxi, 2009; 10(5): 329-330.

11. Maraş Genç H, Uyur Yalçın E, Rosti RÖ, Gleeson JG, Kara B. TSEN54 gene-related pontocerebellar hypoplasia

\section{Závěr}

Touto kazuistikou jsme chtěli upozornit na existenci velmi vzácné a málo známé skupiny geneticky podmíněných onemocnění, pontocerebellárních hypoplázií. Třebaže se manifestujíjiž v raném dětském věku, je třeba na ně pomýšlet i v diferenciální diagnostice cerebellárních ataxií v mladém věku dospělém. Vzhledem k možnosti prenatálního testování u vybraných klinických jednotek je stanovení přesné diagnózy důležité nejen pro samotného pacienta, ale i jeho pokrevní príbuzné

type 2 presenting with exaggerated startle response: report of two cases in a family. Turk J Pediatr. 2015 May-Jun 57(3): 286-289

12. Mochida GH, Ganesh VS, de Michelena MI, Dias H, Atabay KD, Kathrein KL, Huang HT, Hill RS, Felie JM, Rakiec D, Gleason D, Hill AD, Malik AN, Barry BJ, Partlow JN, Tan WH, Glader LJ, Barkovich AJ, Dobyns WB, Zon LI, Walsh CA. CHMP1A encodes an essential regulator of BMI1-INK4A in cerebellar development. Nat Genet. 2012; 44: 1260-1264.

13. Namavar Y, Barth PG, Poll-The BT, Baas F. Classification, diagnosis and potential mechanisms in pontocerebellar hypoplasia. Orphanet J Rare Dis. 2011; 6: 50

14. Patel MS, Becker LE, Toi A, Armstrong DL, Chitayat D. Severe, fetal-onset form of olivopontocerebellar hypoplasia in three sibs: PCH type 5? Am J Med Genet A. 2006; 140: 594-603. 15. Prior TW, Russman BS.Spinal Muscular Atrophy. GeneReviews ${ }^{\oplus}$ [Internet] 2000 Feb 24 [Updated 2013 Nov 14]. 16. Richard Gatti, MD Ataxia-Telangiectasia Synonym: Louis-Bar Syndrome Initial Posting: March 19, 1999; Last Update: March 11, 2010.

17. Rudnik-Schöneborn S, Barth PG, Zerres K. Pontocerebellar hypoplasia. Am J Med Genet C Semin Med Genet. 2014; 166C(2): 173-183. 